\title{
Candesartan, an Angiotensin II AT, - Receptor Blocker and PPAR- $\gamma$ Agonist, Reduces Lesion Volume and Improves Motor and Memory Function After Traumatic Brain Injury in Mice
}

\author{
Sonia Villapol ${ }^{1,2}$, Alexandra K Yaszemski ${ }^{1,2}$, Trevor T Logan ${ }^{1,2}$, Enrique Sánchez-Lemus ${ }^{3}$, Juan M Saavedra ${ }^{3}$ \\ and Aviva J Symes*, ${ }^{*}, 2$
}

'Center for Neuroscience and Regenerative Medicine, Bethesda, MD, USA; ${ }^{2}$ Department of Pharmacology, Uniformed Services University of the Health Sciences, Bethesda, MD, USA; ${ }^{3}$ Section on Pharmacology, Division of Intramural Research Programs, Department of Health and Human Services, National Institute of Mental Health, National Institutes of Health, Bethesda, MD, USA

\begin{abstract}
Traumatic brain injury (TBI) results in complex pathological reactions, the initial lesion worsened by secondary inflammation and edema. Angiotensin II (Ang II) is produced in the brain and Ang I| receptor type I (AT,R) overstimulation produces vasoconstriction and inflammation. Ang II receptor blockers (ARBs) are neuroprotective in models of stroke but little is known of their effect when administered in TBI models. We therefore performed controlled cortical impact $(\mathrm{CCl})$ injury on mice to investigate whether the ARB candesartan would mitigate any effects of TBI. We administered candesartan or vehicle to mice $5 \mathrm{~h}$ before $\mathrm{CCl}$ injury. Candesartan treatment reduced the lesion volume after $\mathrm{CCl}$ injury by approximately $50 \%$, decreased the number of dying neurons, lessened the number of activated microglial cells, protected cerebral blood flow (CBF), and reduced the expression of the cytokine TGF $\beta$ I while increasing expression of TGF $\beta 3$. Candesartan-treated mice also showed better motor skills on the rotarod 3 days after injury, and improved performance in the Morris water maze 4 weeks after injury. These results indicate that candesartan is neuroprotective, reducing neuronal injury, decreasing lesion volume and microglial activation, protecting CBF and improving functional behavior in a mouse model of TBI. Co-treatment with a peroxisome proliferator-activated receptor-gamma (PPAR $\gamma$ ) antagonist significantly reduced some of the beneficial effects of candesartan after $\mathrm{CCl}$, suggesting that PPAR $\gamma$ activation may contribute to part or to all of the neuroprotective effect of candesartan. Overall, our data suggest that ARBs with dual AT,R-blocking and PPAR $\gamma$ activation properties may have therapeutic value in treating TBI.

Neuropsychopharmacology (2012) 37, 2817-2829; doi:I0.1038/npp.2012.152; published online 15 August 2012
\end{abstract}

Keywords: traumatic brain injury; candesartan; TGF $\beta$; inflammation; neuroprotection; PPAR $\gamma$

\section{INTRODUCTION}

Traumatic brain injury (TBI) results in complex pathophysiological reactions. The initial direct injury is considerably worsened by secondary cascades that activate many different signaling pathways. These cascades result in blood-brain barrier dysfunction, edema formation, an enhanced inflammatory response, increased cell death, gliosis, and cerebral cavity formation (O'Connor et al, 2011). TBI also often results in motor and learning impairment leading to long-term disability (Hamm, 2001;

\footnotetext{
*Correspondence: Dr AJ Symes, Department of Pharmacology, Uniformed Services University of the Health Sciences, 430I Jones Bridge Road, Bethesda, MD 208 I4, USA, Tel: + I 3012953234 ,

Fax: + I 301295 3220, E-mail: aviva.symes@usuhs.edu

Received 27 February 2012; revised 18 July 2012; accepted 20 July 2012
}

O'Connor et al, 2011; Santos et al, 2005). These secondary cascades, which occur minutes to days following injury, provide a therapeutic window to intervene, to prevent, or reduce the extent of the secondary damage. As a result of the multiple mechanisms initiated by brain injury that lead to neuronal dysfunction, it would seem that a drug that had multimodal action to combat the harmful secondary cascades would be advantageous to treat recovery from TBI. Drugs that block the angiotensin II (Ang II) receptors (Ang II receptor blockers, ARBs) are neuroprotective, antiinflammatory, and vasodilatory attacking three potentially devastating sequelae of TBI (Benigni et al, 2010). In addition, ARBs are already widely used FDA-approved drugs with limited side effects that have significant benefit in animal models of stroke (Thone-Reineke et al, 2006). However, little is known of the involvement of Ang II in the response to TBI, or the ability of ARBs to have a beneficial therapeutic effect. The probable beneficial properties of 
ARBs together with their known efficacy in treating stroke made a strong case for investigating their potential for treating TBI.

Ang II is a multifunctional effector hormone that contributes to the regulation of blood pressure, vascular tone, and fluid volume (Davisson et al, 2000). Ang II is synthesized from the precursor angiotensinogen, in most tissues including the brain (Paul et al, 2006; Saavedra, 1992). In the brain, Ang II is involved in the regulation of cerebral blood flow (CBF), the autonomic and hormone systems, and stress response (Benicky et al, 2011; Saavedra et al, 2011). Ang II type 1 receptors $\left(\mathrm{AT}_{1} \mathrm{R}\right)$ are responsible for most of the well-characterized peripheral and central actions of Ang II (Benicky et al, 2011). However, excessive $\mathrm{AT}_{1} \mathrm{R}$ stimulation leads to inflammation, increasing oxidative stress, and endothelial dysfunction both in the periphery (Savoia and Schiffrin, 2007) and in the brain (Ozacmak et al, 2007). In the brain, excessive $\mathrm{AT}_{1} \mathrm{R}$ stimulation has been linked to cerebrovascular remodeling and inflammation leading to neuronal injury and vulnerability (Ando et al, 2004a; Nishimura et al, 2000; Yamakawa et al, 2003; Zhou et al, 2005). In addition, reduced Ang II formation offers protection from stroke, because the core lesion area after middle cerebral artery occlusion is significantly reduced in angiotensinogen-knockout mice (Maeda et al, 2009).

The neuroprotective effect of ARBs has been demonstrated in animal models and clinical studies. Peripherally administered ARBs cross the blood-brain barrier and have direct CNS effects (Nishimura et al, 2000), reducing both cerebrovascular remodeling and inflammation (Ando et al, 2004b; Yamakawa et al, 2003; Zhou et al, 2005). ARBs ameliorate stroke by protecting the cerebrovascular flow (Engelhorn et al, 2004; Ito et al, 2001; Nishimura et al, 2000); lessen the cognitive impairment seen after whole brain irradiation in rats (Robbins et al, 2010) and reduce brain inflammation protecting the rats from behavior associated with sickness and depression (Benicky et al, 2011).

Several large clinical studies have demonstrated that ARBs prevent the cognitive dysfunction produced by stroke in patients with and without hypertension (Fogari and Zoppi, 2004; Hansson et al, 1999; Igase et al, 2012; Meredith et al, 2004; Poon, 2008; Van Mieghem et al, 2010; Zanchetti and Elmfeldt, 2006). Furthermore, ARBs reduce the incidence and progression of Alzheimer's disease and dementia in hypertensive patients more effectively than other antihypertensive medications (Davies et al, 2011).

We hypothesized that treatment with candesartan may improve the behavioral and neurological outcome after TBI, in a manner similar to that observed in rodent models and in humans affected by stroke (Awad, 2011; Guan et al, 2011; Ito et al, 2001; Liu et al, 2008; Stenman and Edvinsson, 2004). We therefore investigated the effect of administering candesartan to mice just before they received a controlled cortical impact (CCI) injury to determine whether short- or long-term inhibition of central $\mathrm{AT}_{1} \mathrm{Rs}$ would reduce the cortical and hippocampal damage and hence protect against cognitive impairment. While we were completing these data, a report was published demonstrating that administration of low doses of candesartan to mice within $4 \mathrm{~h}$ of TBI prevented secondary brain damage and reduced cerebral inflammation at $24 \mathrm{~h}$ post-injury (Timaru-Kast et al, 2012). Our studies confirm and extend these observations. We show that administration of candesartan can reduce cell death, inflammation and lesion volume, reduce TGF $\beta 1$ expression post-injury, and improve functional outcome up to 4 weeks after injury.

Some ARBs, including candesartan, are peroxisome proliferator-activated receptor-gamma (PPAR $\gamma$ ) agonists (An et al, 2010; Benson et al, 2004; Erbe et al, 2006). $\operatorname{PPAR} \gamma$ is a nuclear hormone receptor whose activation leads to beneficial effects in the regulation of multiple pathways. PPAR $\gamma$ activation mitigates some of the major factors influencing TBI outcome, such as excessive inflammation, reduction of oxidative stress, and inhibition of apoptosis in various tissues, including the brain (Gillespie et al, 2011; Ricote et al, 1998; Rotman and Wahli, 2010). $\operatorname{PPAR} \gamma$ agonists have been investigated as potential therapeutics for treating TBI (Gillespie et al, 2011). We asked whether the beneficial effects of candesartan was a consequence of both $\mathrm{AT}_{1} \mathrm{R}$ blockade and PPAR $\gamma$ agonist activity. We show that candesartan's actions may indeed be mediated by the dual activities of $\mathrm{AT}_{1} \mathrm{R}$ blockade and PPAR $\gamma$ activation. Therefore, our studies show that candesartan exerts broad and long-term beneficial effects, and thus may be a potentially valuable therapeutic for treating TBI.

\section{MATERIALS AND METHODS}

\section{Animals and CCI Injury}

All animal studies were approved by the USUHS Institutional Animal Care and Use Committee and were conducted in accordance with the NRC guide to the Care and Use of Laboratory Animals. Nine-week-old male C57BL/6 mice (NCI, MD), weighing 22-28 g, were kept under 12:12 light and dark cycle with access to food and water ad libitum. Typically, surgery was done after 1 week of recovery from transportation-related stress. Mice were anaesthetized with isoflurane (3\% induction : $1.5 \%$ maintained) and placed in a stereotaxic frame. Body temperature was kept constant using an isothermal heating pad (Stoelting, IL) throughout surgery. The skull was fixed in a stereotactic frame and a craniotomy was performed above the left parietal cortex. We performed moderate CCI injury (coordinates; $2 \mathrm{~mm}$ lateral, $-2 \mathrm{~mm}$ posterior to Bregma) at an impact depth of $2 \mathrm{~mm}$, with a $2 \mathrm{~mm}$ diameter round impact tip (speed $3.6 \mathrm{~m} / \mathrm{s}$, dwell time $100 \mathrm{~ms}$ ) and $12^{\circ}$ angle of dura mater, using an electromagnetically driven CCI injury device (Impact One stereotaxic impactor CCI, Leica Microsystems Gmbh, Wetzlar, Germany). The bone flap was replaced but not sealed, the skin was sutured, and the mice were allowed to recover fully from anesthesia before transfer to their cages. Sham-injured animals received the same craniotomy without the impact injury.

\section{Drug Treatment}

Osmotic minipumps were employed to dispense candesar$\tan (1 \mathrm{mg} / \mathrm{kg} /$ day) continuously until killing at 3 or 28 days post-injury (dpi). Minipumps (ALZET, Cupertino, CA: model 1007; delivering $0.5 \mu \mathrm{l} / \mathrm{h}$ for 7 days; or model 1004 ; delivering $0.11 \mu \mathrm{l} / \mathrm{h}$ for 28 days) were filled with candesartan 
(CV-11974, Astra-Zeneca, Sweden) dissolved in $0.1 \mathrm{~N}$ $\mathrm{Na}_{2} \mathrm{CO}_{3}, \mathrm{pH}=7.4(2 \mathrm{mg} / \mathrm{ml}$ for model $1007 ; 9.2 \mathrm{mg} / \mathrm{ml}$ for model 1004), or vehicle $\left(0.1 \%\right.$ saline and $0.1 \mathrm{~N} \mathrm{Na}_{2} \mathrm{CO}_{3}$ at $\mathrm{pH}=7.4$ ) the day before implantation and primed at $37^{\circ} \mathrm{C}$ overnight. At $5 \mathrm{~h}$ before CCI injury, animals were anesthetized with isoflurane and the loaded minipumps were implanted at the back of the neck of each mouse so that the drug was delivered subcutaneously. For some experiments (presented in Figures 3 and 6) mice were administered drug or vehicle by i.p. injections with either candesartan (1 mg/ $\mathrm{kg} /$ day), vehicle, and/or the PPAR $\gamma$ antagonist, (T0070907, $1.5 \mathrm{mg} / \mathrm{kg}$, Sigma-Aldrich). At the time of killing (either 1, 3 or $28 \mathrm{dpi}$ ), mice were anesthetized with ketamine/xylazine and killed by decapitation.

\section{Determination of CBF and Blood Pressure}

Regional CBF (rCBF) was measured around the cortical impact area using a laser-Doppler flowmeter (PeriFlux System 5000 LDPM, Perimed). Changes in rCBF were measured in the impact area using a flexible fiber optic extension to the LDPM probe tip 404 as described previously (Villapol et al, 2011). Changes in rCBF were expressed as the percentage of the baseline value recorded before CCI injury. Animals were anesthetized with isoflurane for 1-2 min while rCBF was measured. The rCBF values were taken at basal levels before, $2 \mathrm{~min}, 2 \mathrm{~h}$, and $18 \mathrm{~h}$ after cortical impact. Tail blood pressure was obtained using the CODA mouse tailcuff system, an indirect blood pressure method that utilizes volume pressure recording sensor, coupled to a PC-based data acquisition system (Kent Scientific, CT). A minimum of 10 measurements were taken from each mouse.

\section{Behavioral Testing}

To examine the effects of the candesartan on neurological outcome after CCI injury, two investigators who were blinded to the treatment status of the mice performed behavioral tests. A rotarod test was used to evaluate motor coordination. Mice were trained on the rotarod (Ugo Basile, Collegeville, PA, USA) for 2 days before injury, and tested at specific time points after injury. Each day, mice performed at least two trials, separated by a $15-$ min rest period. Mice were allowed to stand for $15 \mathrm{~s}$ on the rod before the rotarod started to rotate with speed linearly increasing from 4 to 40 r.p.m. in $2 \mathrm{~min}$. The average latency before animals fell off the rod was recorded.

\section{Morris Water Maze Test Used to Evaluate Spatial Learning and Memory Talks}

The Morris water maze (MWM) was performed as previously described (Hamm, 2001) from 24 to $28 \mathrm{dpi}$. The $4 \mathrm{ft}$ diameter tank (Stoelting Morris) was filled with tap water $\left(23-25^{\circ} \mathrm{C}\right)$ to a depth of $25 \mathrm{~cm}$ and a clear plastic platform $(4 \times 12$ inch) was placed in the northwest quadrant of the tank $1 \mathrm{~cm}$ beneath the surface of the water. Highly visible black cues were placed on the walls of the room. Initial trial: on day 1 ( $24 \mathrm{dpi}$ ), each mouse was placed on the platform in the tank and kept there for $15 \mathrm{~s}$. Follow-up trials: on days $2-5$, each mouse underwent four trials, each separated by $2 \mathrm{~min}$. Mice were randomly placed into one of the four quadrants and allowed $60 \mathrm{~s}$ to swim to the platform. If a mouse did not reach the platform in $60 \mathrm{~s}$, they were gently guided to the platform by the investigator and allowed to remain there for $15 \mathrm{~s}$. A video tracking system recorded all parameters including swim speed and the latency to find the platform. Final probe trial: on day $5(28 \mathrm{dpi}), 1 \mathrm{~h}$ after the last training trial, a probe trial was performed with mice placed in the tank without the platform. The time spent in the quadrant where the platform had been located was recorded and compared with time spent in the other three quadrants. All data were analyzed with ANY-maze 4.50 software (Stoelting, Wood Dale, IL).

\section{Tissue Preparation and Histology}

Animals were randomized into two groups; one group was used for histology and binding analyses and the second group for qPCR. For histology and binding analyses, mice were killed at $3 \mathrm{dpi}$, brains were dissected, fresh frozen in cold isopentane on dry ice, and stored at $-80^{\circ} \mathrm{C}$. Fresh frozen brains were cut to $16 \mu \mathrm{m}$ thick coronal sections on a cryostat, mounted on gelatin-coated glass slides and stored at $-80^{\circ} \mathrm{C}$ until use. To quantify $\mathrm{AT}_{1} \mathrm{R}$ mRNA expression with qPCR, mice were killed at $1 \mathrm{dpi}$, brains dissected, and sliced into $300 \mu \mathrm{m}$ thick sections with a cryostat. Punches were taken from the pericontusional cortex (5 punches per section) using a $1 \mathrm{~mm}$ microdissection punch (Harris Uni-core needles, Electron Microscopy Sciences, Hatfield, $\mathrm{PA})$. To measure mRNA levels of $\operatorname{PPAR} \gamma$ brains were dissected at $3 \mathrm{dpi}$ and a single punch was taken from the cortical lesion region using a $5 \mathrm{~mm}$ punch cannula (Zivic Instruments, Pittsburgh, PA).

\section{Cell Death Assay}

Sections were processed for DNA strand breaks (TUNEL assay, labeling of fragmented DNA) using the fluorescence In Situ Cell Death Detection Kit (Roche, IL), according to the manufacturer's instructions. TUNEL-positive nuclei were counted in cortical and hippocampal regions in 3 to 5 coronal sections for each animal, with five animals per group.

\section{RNA Isolation and $\mathrm{qPCR}$ of $\mathrm{AT}_{1} \mathrm{R}$ and PPAR $\gamma$}

The extracted punches were immediately placed in TRIzol reagent (Invitrogen, CA) and homogenized by trituration with a pipette, then stored at $-80^{\circ} \mathrm{C}$ until use. RNA was isolated by adding 0.2 volumes of chloroform, centrifuging at $16000 \mathrm{~g}$ for $15 \mathrm{~min}$, and extracting the aqueous layer. RNA was further purified using the RNeasy Lipid Tissue Mini kit (Qiagen, MD) and treated with RNase-Free DNase according to the manufacturer's instructions. RNA was quantified and RNA integrity checked by agarose gel electrophoresis. qPCR was performed using SYBR Green qPCR MasterMix (Qiagen) with primers specific for murine $\mathrm{AT}_{1 \mathrm{~A}}$ type receptor (forward $\left(5^{\prime}-3^{\prime}\right)$ : AGCCTGCGTCTTGTT TTGAG, reverse $\left(5^{\prime}-3^{\prime}\right)$ : GCTGCCCTGGCTTCTGTC), $\mathrm{AT}_{1}$ total receptor (forward $\left(5^{\prime}-3^{\prime}\right)$ : TGTTCCTGCTGCTCACGT GTCTC, reverse $\left(5^{\prime}-3^{\prime}\right)$ : CATCAGCCAGATGATGATGC), and PPAR $\gamma$ (forward $\left(5^{\prime}-3^{\prime}\right)$ : CACAATGCCATCAGGTTTGG, reverse $\left(5^{\prime}-3^{\prime}\right)$ : GTGATTTGTCCGTTGTCTTTCC). The amplification 
conditions consisted of denaturation and enzyme activation at $95{ }^{\circ} \mathrm{C}$ for $10 \mathrm{~min}$, followed by 40 cycles of $95^{\circ} \mathrm{C}$ for $15 \mathrm{~s}$ and $60{ }^{\circ} \mathrm{C}$ for $60 \mathrm{~s}$ (CFX96, Bio-Rad). mRNA expression levels were normalized to the housekeeping gene cyclophilin A (reverse $\left(5^{\prime}-3^{\prime}\right)$ : GCACTGGAGAGAAAGGATTTGG, forward $\left(5^{\prime}-3^{\prime}\right)$ : CCAGTGCCATTATGGCGTGT). Quantification of relative changes in mRNA levels between samples taken from animals after surgery with those from naive mice were calculated using the delta delta threshold cycle $(\Delta \Delta \mathrm{Ct})$ method (Susarla et al, 2011).

\section{Immunohistochemistry}

Fresh frozen $16 \mu \mathrm{m}$ thick sections were post-fixed in $4 \%$ paraformaldehyde for $1 \mathrm{~h}$. Sections were blocked with $10 \%$ normal goat serum in PBS and $0.1 \%$ Triton X-100 (TX) for $1 \mathrm{~h}$. The following primary antibodies were incubated at $4{ }^{\circ} \mathrm{C}$ overnight anti-GFAP, mouse monoclonal $(1: 200$, Millipore, CA); anti-NeuN, mouse monoclonal (1:200, Chemicon, Temecula, CA) for mature neurons; and antiIba-1, rabbit polyclonal (1:100, Wako,VA) for microglia; anti-TGF $\beta 1$ rabbit polyclonal (IDFR-B, 1:1000, kind gift of Dr Flanders, NIH) and anti-TGF $\beta 3$ (1:1000, sc-83, Santa Cruz Biotechnology, CA). This novel TGF $\beta 1$ antiserum does not stain sections taken from TGF $\beta 1$ knockout mice (manuscript in preparation). Sections were washed in PBS and $0.1 \%$ Triton X-100 (PBS-T) three times and incubated with the corresponding Alexa Fluor 568-conjugated IgG secondary antibodies (all 1:1000; Jackson Immunoresearch, West Grove, PA) for $2 \mathrm{~h}$ at room temperature. Sections were rinsed with PBS and distilled water and coverslipped with ProLong Gold antifade reagent with DAPI (Invitrogen, Chicago, IL). Images were acquired on an Olympus BX61 with attached qImaging Retiga EXi Aqua CCD camera, and iVision software (BioVision Technologies, Exton, PA).

\section{Ang II Receptor Autoradiography}

For receptor autoradiography, brains were removed from mice that were either treated or not treated with candesartan for 3 days, snap frozen, and $16 \mu \mathrm{m}$ thick sections were cut in a cryostat at $-15^{\circ} \mathrm{C}$. Sections were incubated with $\left[{ }^{125} \mathrm{I}\right]$-sarcosine1Sar1-ANG II ([ $\left.{ }^{125 \mathrm{I}}\right]$-Sar ${ }^{1}$-ANG II; ARC, St Louis, MO) as described previously (Tsutsumi and Saavedra, 1991). Optical densities of autoradiograms were analyzed by computerized densitometry using Scion Image 4.0.2 (Scion, Frederick, MD) based on the NIH Image program.

\section{Quantification and Image Analysis}

The lesion area was determined in every 16th section throughout the entire lesion (a total of 9 sections at $256 \mu \mathrm{m}$ intervals). The area of each of the corresponding ipsilateral hemispheres was similarly determined. Lesion volume was obtained by multiplication of the sum of the lesion areas by the distance between sections. Percent lesion volume was calculated by dividing the lesion volume by the total ipsilateral hemisphere volume (similarly obtained by multiplying the sum of the areas of the ipsilateral hemispheres by the distance between sections). To obtain cell counts of specific labeled cells, each labeled cell was counted with the $\times 40$ objective in five fields per section, at least three sections per animal, $n=5-12$. Quantitative image analysis of the immunoreactive areas for $\operatorname{TGF} \beta 1, \operatorname{TGF} \beta 3$, and Iba- 1 were performed on 15 cortical and hippocampal sections through the level of impact site (AP $-2.0 \mathrm{~mm}$ ) taken with the $\times 20$ objective and using the same densitometric analysis method as described previously (Villapol et al, 2011). Immunofluorescence intensity was calculated using the threshold method and defined as the number of pixels, divided by the total area $\left(\mathrm{mm}^{2}\right)$ in the imaged field with the average background subtracted. All images were captured and analyzed using iVision.

\section{Statistical Analysis}

All data in this study are expressed as mean \pm SEM, except for lesion volume presented as mean \pm SD. ${ }^{*} p<0.05$ or less was considered statistically significant. Intergroup differences were evaluated by one-way ANOVA followed by the Newman-Keuls Multiple Comparison test. CBF and blood pressure data were analyzed by two-way ANOVA with Bonferroni post-tests. All statistics were performed with Prism 5.03 software (GraphPad Software, San Diego, CA).

\section{RESULTS}

\section{Candesartan Treatment Reduces Lesion Volume and Cell Death after CCI}

We implanted an osmotic minipump dispensing candesar$\tan (1 \mathrm{mg} / \mathrm{kg} /$ day $)$ starting $5 \mathrm{~h}$ before the injury and continuously until the time of killing (Figure 1a). Examination of cresyl-violet stained sections of brains taken from either candesartan- or vehicle-treated mice showed that candesartan reduced the mean lesion volume at 3 and 28 dpi. At 3 dpi, mice treated with candesartan had a $43 \%$ decrease in lesion volume compared with vehicle-treated mice $\left({ }^{* *} p<0.005, n=7-8\right.$ ) (Figure $1 \mathrm{~b}$ ). This difference was maintained at $28 \mathrm{dpi}$, where treatment with candesartan reduced the lesion cavity by approximately $31 \%\left({ }^{*} p<0.05\right.$, $n=11-12$ ) (Figure 1b). To determine whether the beneficial effect of candesartan was due in part to a reduction in cell death, we performed a TUNEL assay on sections taken from candesartan- or vehicle-treated mice at $3 \mathrm{dpi}$. Candesartantreated injured mice (CCI-CD) had a significantly lower number of TUNEL-positive cells compared with vehicletreated injured (CCI-VH) in the cortex $\left({ }^{*} p<0.05\right)$, (Figures $2 \mathrm{a}-\mathrm{c})$. Double staining with TUNEL and NeuN showed that approximately $80 \%$ of TUNEL-positive cells corresponded with neurons (data not shown), indicating that candesartan prevented significant neuronal cell death in the perilesional area. Furthermore, there were significantly fewer TUNELpositive cells in the CA1, CA3, and dentate gyrus regions of the ipsilateral hippocampus in candesartan-treated mice after CCI (Figures 2d-f). Thus, candesartan reduced the amount of cell death and specifically neuronal cell death after CCI. To ensure that candesartan was acting as an antagonist at $\mathrm{AT}_{1} \mathrm{R}$ in the brain, we analyzed radiolabeled ligand binding to the $\mathrm{AT}_{1} \mathrm{R}$. There was an approximately $45 \%$ reduction in binding to the $\mathrm{AT}_{1} \mathrm{R}$ in both the 
a

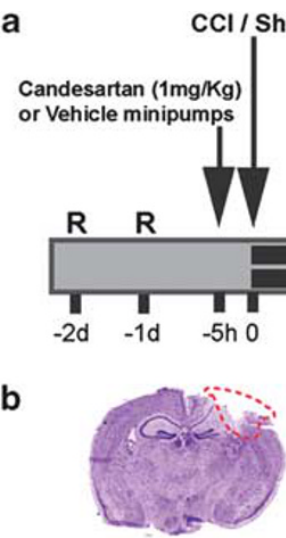

VH

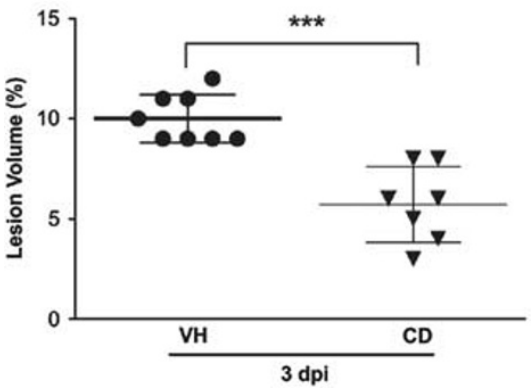

Sacrifice

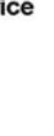

$3 d$

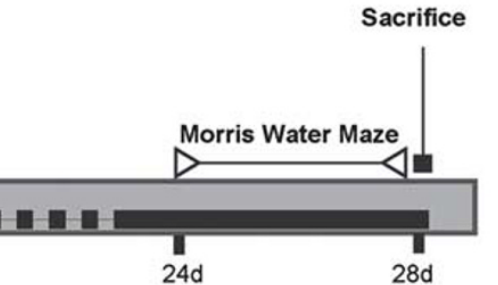

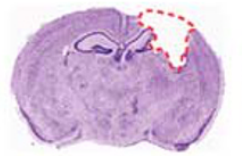

VH

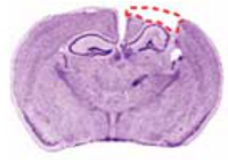

CD

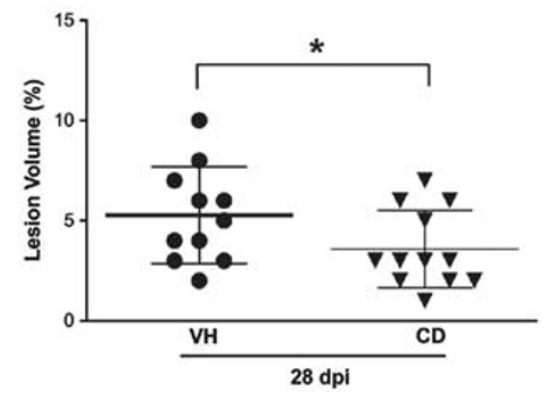

Figure I Neuroprotective effect of candesartan treatment on lesion volume following CCl injury in mice. (a) Experimental design. Osmotic pumps

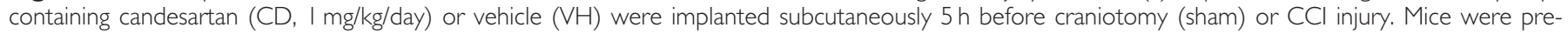

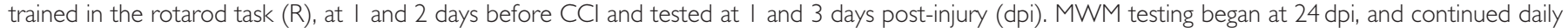

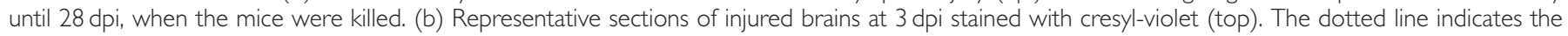
lesion area composed of the cavity and edematous area. Candesartan treatment significantly reduced the mean lesion volume by $43 \%$ compared with vehicle-treated mice at $3 \mathrm{dpi}($ mean $\pm \mathrm{SD} n=7-8$, **** $p<0.001$ ) and by $31 \%$ at $28 \mathrm{dpi}(\mathrm{mean} \pm \mathrm{SD}, n=1 \mathrm{I}-12, * p<0.05)$.

paraventricular nucleus (PVN) and the subfornical organ (SFO), studied in sections taken from mice treated with candesartan for 3 days, in comparison with binding to sections taken from mice treated with vehicle only (Supplementary Figure 2). To determine whether expression or function of the $\mathrm{AT}_{1} \mathrm{R}$ was altered after injury, we examined the expression of $\mathrm{AT}_{1} \mathrm{R}$ mRNA together with ligand-specific binding in different brain regions after TBI. In rodents, there are two isoforms of $\mathrm{AT}_{1} \mathrm{Rs} ; \mathrm{AT}_{1 \mathrm{a}}$ and $\mathrm{AT}_{1 \mathrm{~b}}$ receptors (Burson et al, 1994; Johren and Saavedra, 1996). qPCR analysis indicated no change in expression in either total $\mathrm{AT}_{1} \mathrm{R}\left(\mathrm{AT}_{1 \mathrm{a}}+\mathrm{AT}_{1 \mathrm{~b}}\right)$ mRNA or $\mathrm{AT}_{1 \mathrm{a}} \mathrm{R}$-specific mRNA at $1 \mathrm{dpi}$, in comparison with expression in sham mice (Supplementary Figure 3). Autoradiography also showed no alteration in ligand-specific binding to the PVN or SFO after injury. $\mathrm{AT}_{1} \mathrm{R}$ density in the cortex was not sufficient to detect by autoradiography. Taken together, our data show no gross difference in expression of the $\mathrm{AT}_{1} \mathrm{R}$ after $\mathrm{CCI}$ injury.

\section{Candesartan Treatment Reduces Microglial Activation}

To determine whether candesartan altered the activation or survival of glial cells, we examined staining for glial-specific markers in sections taken from candesartan- or vehicletreated mice at $3 \mathrm{dpi}$. Candesartan treatment significantly decreased the number of Iba-1-positive cells and the amount of Iba-1 immunoreactivity in the perilesional area at $3 \mathrm{dpi}$ (Figures $2 \mathrm{~g}-\mathrm{j})\left({ }^{*} P<0.05\right)$. Candesartan treatment also led to a change in morphology of microglia, with reduced numbers of microglia showing hypertrophy or ameboid morphology (Figures $2 \mathrm{~g}$ and $\mathrm{h}$ with inset $\mathrm{g}^{\prime}$ and $h$, respectively). Candesartan treatment did not alter the number of GFAP-positive astrocytes, or mature oligodendrocytes (APC-positive cells) in the perilesional area at $3 \mathrm{dpi}$ (data not shown). Thus, the glial-specific effects of candesartan are restricted to reducing microglial activation.

\section{Blockade of $\mathrm{AT}_{1}$ Receptors Increases $\mathrm{CBF}$ but Does not Significantly Affect Blood Pressure after CCI Injury}

Laser-Doppler analysis showed that CBF decreased immediately after CCI to approximately $50 \%$ of the pre-injury level in both candesartan-treated and -untreated mice (Figure 3a). At 2 and $18 \mathrm{~h}$ after CCI, CBF recovered more quickly in candesartan-treated mice than in mice treated with vehicle. Indeed at $18 \mathrm{~h}$ after injury in mice treated with candesartan, $\mathrm{CBF}$ had rebounded to just above pre-injury levels (Figure 3a). To determine whether the dose of candesartan used in these experiments altered blood pressure, we recorded blood pressure using the indirect tail-cuff system to obtain baseline levels before injury and at 2 and $18 \mathrm{~h}$ post-injury. In vehicle- and candesartan-treated 


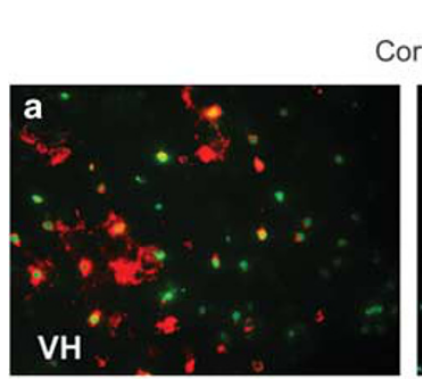

Cortex

TUNEL/NeuN
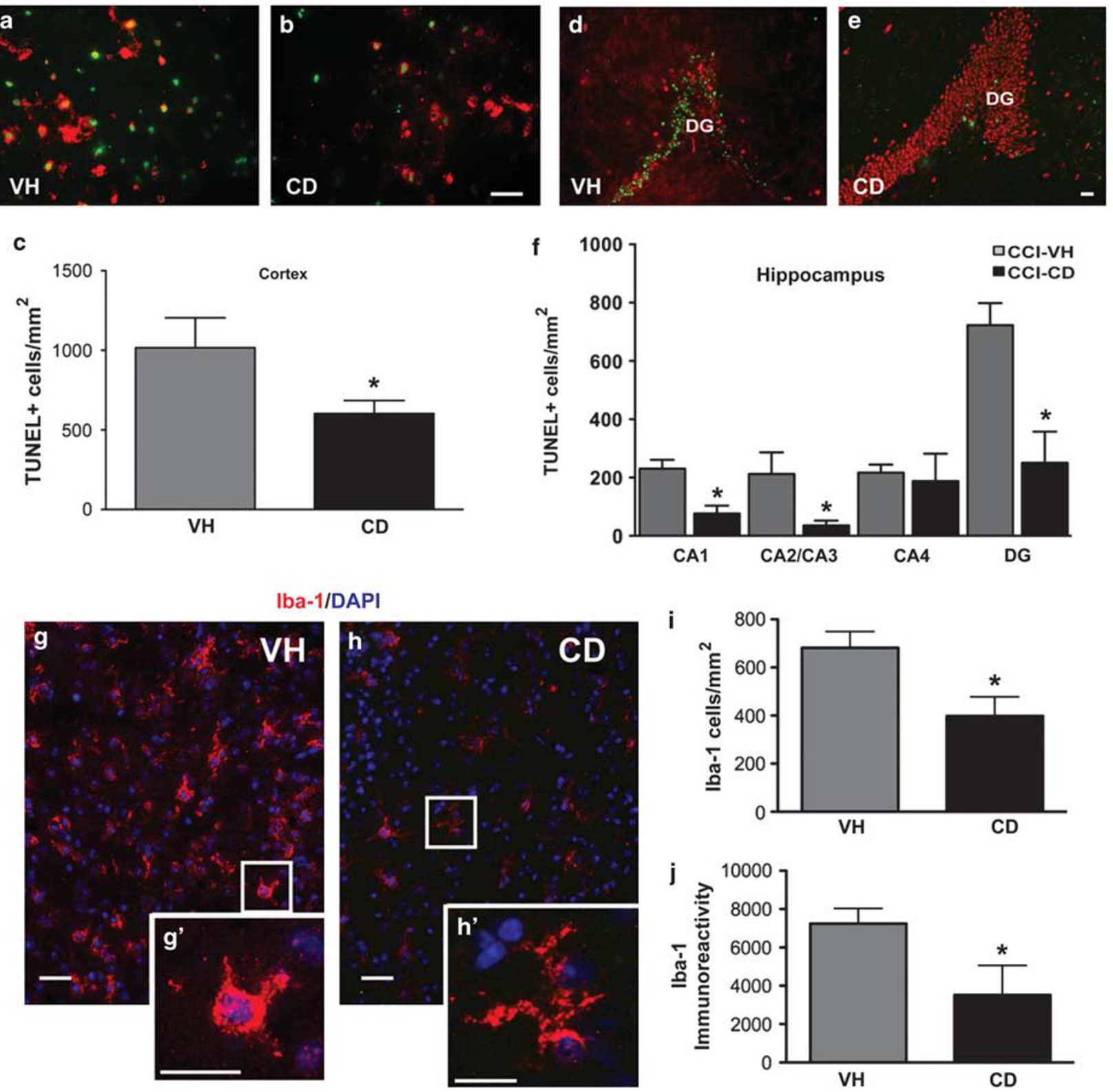

Figure 2 Candesartan treatment reduces the number of dying cells and activated microglial cells after CCl injury. Sections of brains from cortex (a, b) or hippocampus ( $d, e)$ taken from mice treated with candesartan (CD) or vehicle $(\mathrm{VH}$ ) and killed at 3 dpi, showing dying cells, labeled by TUNEL (green) and the neuronal marker NeuN (red) (c, f). Graphs show the number of TUNEL-positive cells at 3 dpi was significantly reduced after injury in CD-treated mice $(\mathrm{CCl}-\mathrm{CD})$ compared with those treated with $\mathrm{VH}(\mathrm{CCl}-\mathrm{VH})$ in the cortex and in the CAI, CA2/3, and dentate gyrus (DG) of the hippocampus (mean $\pm \mathrm{SEM}, n=4$, ${ }^{p} p<0.05$ ). (g, h) At 3 dpi, increased numbers of lba- I-positive microglia (red) were found in brain sections taken from $\mathrm{VH}$-treated mice in comparison with CD-treated mice. In the $\mathrm{VH}$-treated mice, the microglia had the ameboid and hypertrophy morphology characteristic of activated microglia $\left(g^{\prime}\right)$, in comparison with the more ramified morphology in CD-treated animals $\left(h^{\prime}\right)$. (i, j) Quantitative analysis of Iba- I-positive cells in injured cortex showed a reduction after CD treatment in the number of Iba-I-positive cells and in the fluorescence intensity of Iba-I staining in the perilesional area (mean $\pm \mathrm{SEM}, n=4$, * $p<0.05)$. Scale bars represent $50 \mu \mathrm{m}(\mathrm{a}-\mathrm{e}, \mathrm{g}$, and $\mathrm{h})$ and $25 \mu \mathrm{m}\left(\mathrm{g}^{\prime}, \mathrm{h}^{\prime}\right)$.

mice groups, mean baseline blood pressure (before drug administration) was between 114 and $117 \mathrm{~mm} \mathrm{Hg}$. No significant differences in blood pressure were detected between groups after CCI (Figure $3 \mathrm{~b}$ ). We also weighed the mice at 3 and 28 dpi to show that there were no differences between candesartan- or vehicle-treated animals after injury (Supplementary Figure 1).
Effect of Candesartan Treatment Reduces Expression of TGF $\beta 1$, but Increases TGF $\beta 3$ Expression

As ARBs can reduce the amount of TGF $\beta$ expressed in certain tissues (Sun et al, 1998), we sought to determine whether candesartan treatment reduced TGF $\beta$ expression. TGF $\beta 1$ and TGF $\beta 3$ expression was upregulated at $3 \mathrm{dpi}$, with 


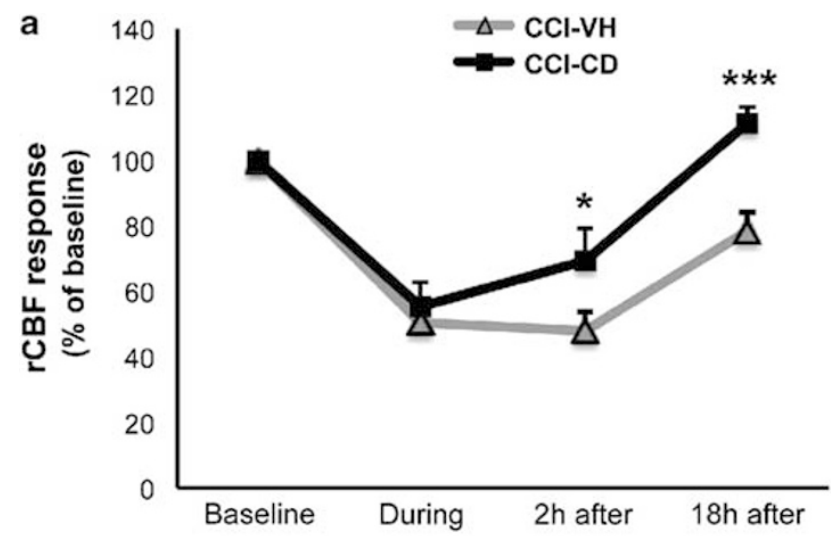

b

Blood Pressure $(\mathrm{mm} \mathrm{Hg})$

\begin{tabular}{lcc}
\hline & CCl-VH & CCl-CD \\
\hline Basal & $114 \pm 9.1$ & $117.4 \pm 7.3$ \\
\hline 2 h after CCI & $101.2 \pm 11.7$ & $91.8 \pm 4.9$ \\
24 h after CCl & $105.6 \pm 3.7$ & $97.85 \pm 5.2$ \\
\hline
\end{tabular}

Figure 3 Changes in the $\mathrm{CBF}$ and blood pressure after $\mathrm{CCl}$ injury in mice treated with vehicle or candesartan. Mice were administered candesartan or vehicle by daily injection for 3 days, starting $5 \mathrm{~h}$ before injury. (a) Regional CBF (rCBF) was measured before injury, during, 2 and $18 \mathrm{~h}$ after injury, and was expressed as \% baseline values (arbitrary units) in the ipsilateral hemisphere. At 2 and $18 \mathrm{~h}$ post-injury, candesartan treatment increased CBF values compared with vehicle. (mean \pm SEM, $n=12-17$, *p $<0.05$, **** $p<0.00$ I). (b) Blood pressure (BP) in CCl mice with vehicle $(\mathrm{CCl}-\mathrm{VH})$ or candesartan-treated (CCl-CD) measured before, and 2 and $24 \mathrm{~h}$ after injury, (mean \pm SEM, $n=6$ )

both cytokines colocalized mainly in reactive astrocytes in the ipsilateral hemisphere (data not shown). Candesartan treatment significantly reduced (by $50 \%$ ) astroglial TGF $\beta 1$ expression in the ipsilateral cortex (Figure 4e) and hippocampus, relative to TGF $\beta 1$ expression in vehicle-treated mice (Figures 4a-f). Surprisingly, candesartan treatment led to an upregulation of astroglial TGF $\beta 3$ expression (approximately $150-200 \%$ ) in the ipsilateral cortex (Figure 4k) and hippocampus compared with TGF $\beta 3$ expression in vehicletreated mice (Figures $4 \mathrm{~g}-\mathrm{l}$ ).

\section{Candesartan Treatment Improves Motor Function, Spatial Learning and Memory Outcome after TBI}

To determine whether candesartan treatment benefited the recovery from injury, we subjected mice to behavioral tests to determine the extent of their functional recovery. Mice were pre-trained on the rotarod for 2 days before CCI injury. All groups of mice behaved similarly during training. Candesartan or vehicle was administered by minipump, implanted $5 \mathrm{~h}$ before injury, as with the rest of the experiments. After CCI injury, mice showed a reduced ability to perform this test, as judged by their shorter latency to fall. At 1 and $3 \mathrm{dpi}$, candesartan-treated mice were able to stay on the rotarod for significantly longer time periods relative to vehicle-treated mice suggesting that candesartan treatment enhances motor performance after TBI, and had a similar effect on the 'sham' operated mice, enhancing their ability to stay longer on the rotarod
(Figure 5a). We found no effect of candesartan treatment on the performance of naive mice in this test (Figure 5a). To determine the effect of candesartan treatment on cognitive ability at a later time point, we evaluated spatial learning and memory by the MWM test (Figure 5b). Mice were trained for 4 trials per day from days 24 through $28 \mathrm{dpi}$. On day 28 , with the platform removed, candesartan-treated mice after CCI spent significantly more time in the correct quadrant, than vehicle-treated mice after CCI, showing that candesartan treatment led to a greater ability to learn and remember $\left(n=7-12,{ }^{*} p<0.05\right)$. There was no observable difference between candesartan- and vehicle-treated mice after sham injury (Figure 5b). These results suggest that candesartan treatment significantly improved spatial learning and memory 4 weeks after CCI injury.

\section{PPAR $y$ Activation may Contribute to the Neuroprotective Effects of Candesartan Following Brain Injury}

We wished to determine whether the PPAR $\gamma$ agonist activity of candesartan was contributing to its efficacy in promoting recovery after CCI. We first examined whether short-term candesartan would elevate $\operatorname{PPAR} \gamma$ mRNA expression. No significant differences were observed in PPAR $\gamma$ mRNA expression in the cortex when comparing naive mice to injured mice, nor between those treated with candesartan compared with mice treated with vehicle at $3 \mathrm{dpi}$ (Figure 6a). We then treated mice with candesartan, the PPAR $\gamma$ antagonist, T0070907, or a combination of candesartan with T0070907, injecting once daily, starting $5 \mathrm{~h}$ before injury as previously. At $3 \mathrm{dpi}$, the beneficial effects of candesartan treatment alone were maintained-with reduced lesion volume, decreased number of Iba-1-positive microglial cells, and an enhanced ability to stay on the rotarod as compared with vehicle-treated mice (Figure 6). However, candesartan's protective effects were reduced or eliminated when given together with T0070907. Mice treated with T0070907 alone showed no significant difference from vehicle-treated mice after CCI. Mice treated with T0070907 together with candesartan showed significantly more microglial activation than mice treated with candesartan alone and were not significantly different from vehicletreated mice (Figure 6c), However, mice co-treated with candesartan and T0070907 developed a lesion volume and showed recovery of motor function that was neither significantly different from vehicle-treated nor candesartan-treated mice (Figures $6 \mathrm{~b}$ and $\mathrm{d}$ ). Thus, PPAR $\gamma$ antagonism diminishes or abolishes the beneficial effects of candesartan treatment on recovery from CCI injury.

\section{DISCUSSION}

The search for an effective therapy to treat TBI patients has been ongoing for many years. After over 30 failed clinical trials for TBI it is becoming increasingly recognized that the sequelae of events after TBI is so complex that a multifunctional approach is more likely to be effective (Loane and Faden, 2010; Marklund and Hillered, 2011). ARBs are known to have a multifaceted action in the brain. They reduce brain inflammation, protect from stroke, and are 

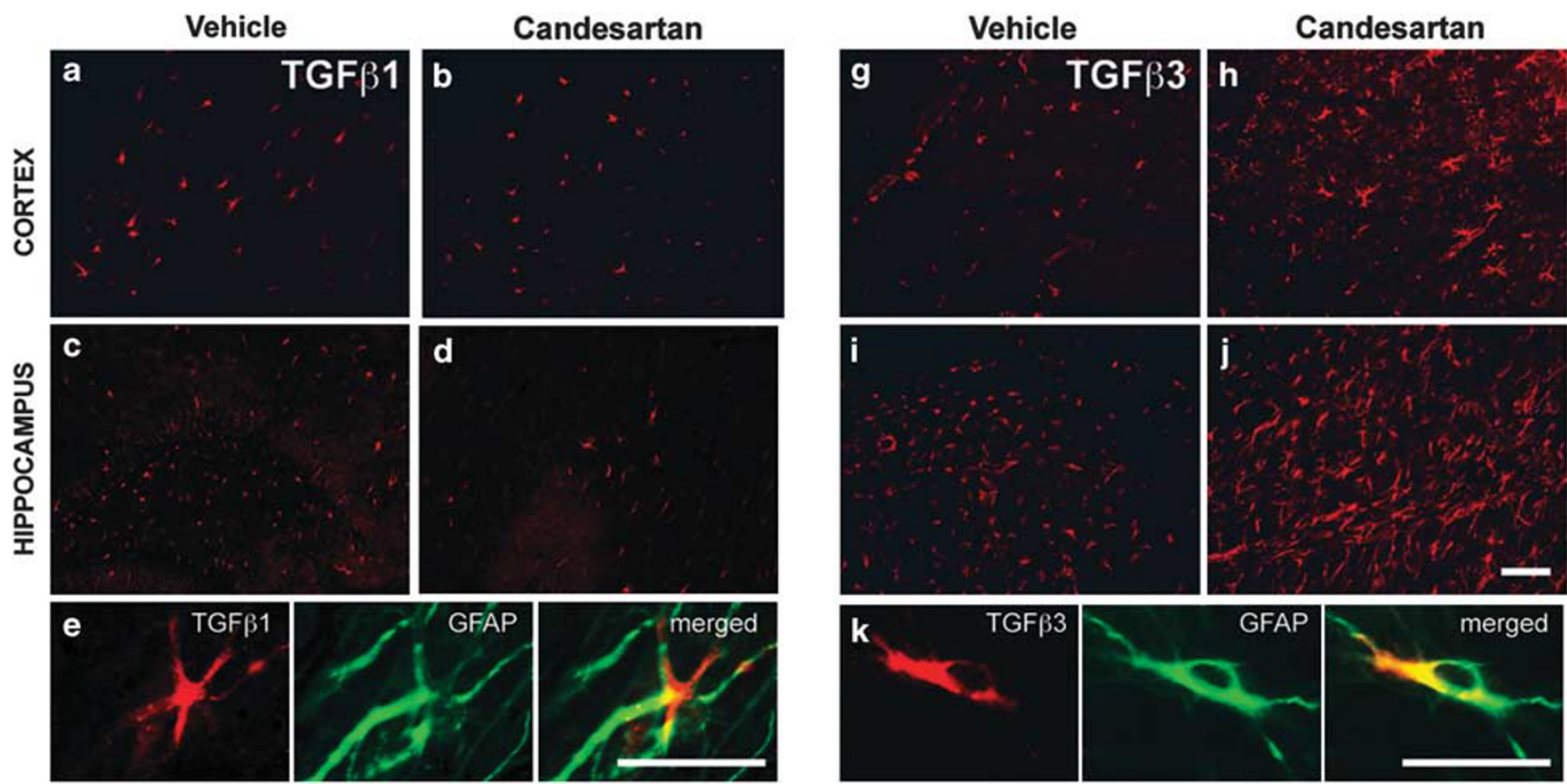

f

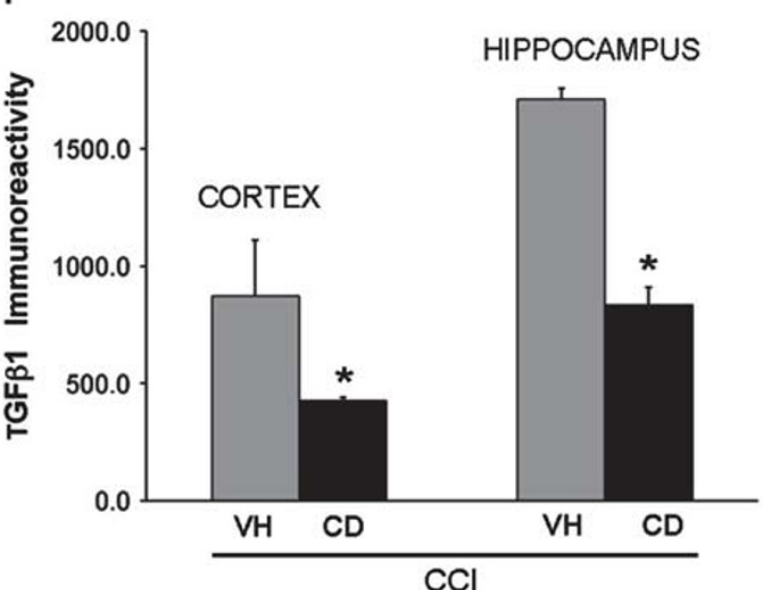

I

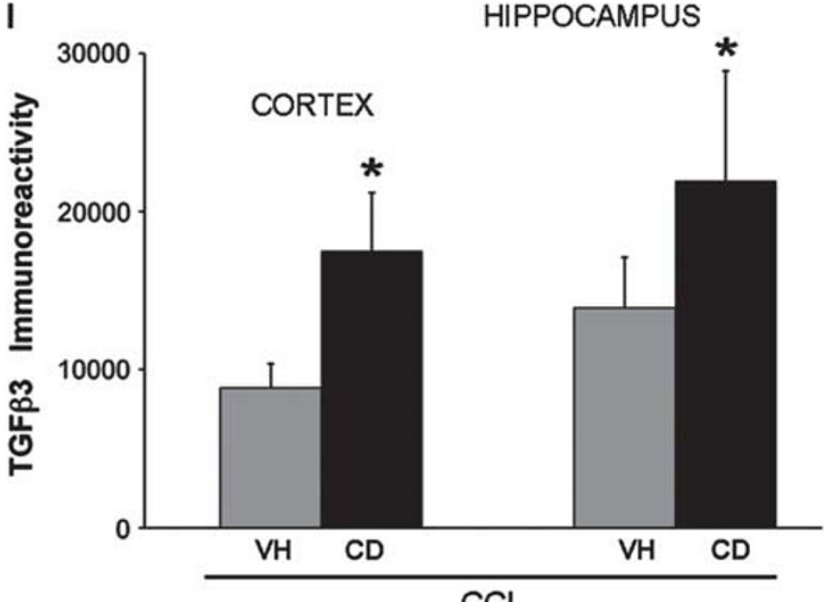

Figure 4 Candesartan treatment modulates TGF $\beta$ I and TGF $\beta 3$ expression after CCI. TGF $\beta$ I immunoreactivity (red) was decreased by candesartan treatment in the ipsilateral cortex (b) and hippocampus (d) in comparison with that in vehicle-treated mice (a, c, respectively). ( $f$ ) Quantitative analysis of TGF $\beta$ I immunoreactivity showed that candesartan treatment led to a reduction of TGF $\beta$ | immunoreactivity of $47 \%$ in the cortex and $49 \%$ in the hippocampus compared with vehicle-treated groups (mean \pm SEM, $n=4$, $* p<0.05$ ). Conversely, candesartan treatment increased TGF $\beta 3$ immunoreactivity in the cortex (h) and hippocampus (j) in comparison with immunoreactivity in vehicle mice (g, $\mathrm{i}$, respectively). (I) Quantitative analysis of TGF $\beta 3$ immunoreactivity showed that candesartan treatment led to an increase in TGF $\beta 3$ immunoreactivity of 50\% in the cortex and 36\% in the hippocampus compared with vehicle-treated groups (mean \pm SEM, $n=4$, * $p<0.05$ ). Higher magnification images show TGF $\beta$ I and TGF $\beta 3$ colocalization with the astroglial marker, GFAP (e, k, respectively). Scale bars represent $50 \mu \mathrm{m}$ (a-d and g-j) and $25 \mu \mathrm{m}(\mathrm{e}, \mathrm{k})$.

directly neuroprotective (Benicky et al, 2011; Kasahara et al, 2010; Rodriguez-Pallares et al, 2008). In this study, we show that administration of the ARB candesartan resulted in a significant reduction in lesion volume, neuronal cell death, and activated microglial cells after CCI injury in the mouse. The improved pathology resulted in better motor and cognitive recovery up to 4 weeks after the injury. We also show that some of the beneficial effects of candesartan may be due to PPAR $\gamma$ activation. Thus, the ARBs may have potential therapeutic value for treating TBI because of their dual action on the $\mathrm{AT}_{1} \mathrm{R}$ and $\mathrm{PPAR} \gamma$ receptors.

TBI initially causes an acute decrease in the CBF, often with periodic episodes of cerebral vasospasm in the days to weeks following injury (Barkhoudarian et al, 2011). These alterations in CBF contribute to the detrimental effects on structure and function resultant from TBI. Studies after ischemia indicate that candesartan exerts an important beneficial effect. Blockade of $\mathrm{AT}_{1} \mathrm{R}$ in the cerebral vasculature decreases vasoconstriction and this diminishes the CBF reduction provoked by ischemia (Ariza et al, 2006; Baranov and Armstead, 2003; Engelhorn et al, 2004; Ito et al, 2002). The mechanisms of CBF protection by ARBs include increased microcirculation, partially through the formation of new collaterals resulting in an increase in vascular flow (Li et al, 2008), increased expression of endothelial nitric oxide synthase in the cerebral vasculature (Yamakawa et al, 2003) and direct reduction of cerebral vasoconstriction resulting from $\mathrm{AT}_{1} \mathrm{R}$ blockade (Ito et al, 
a

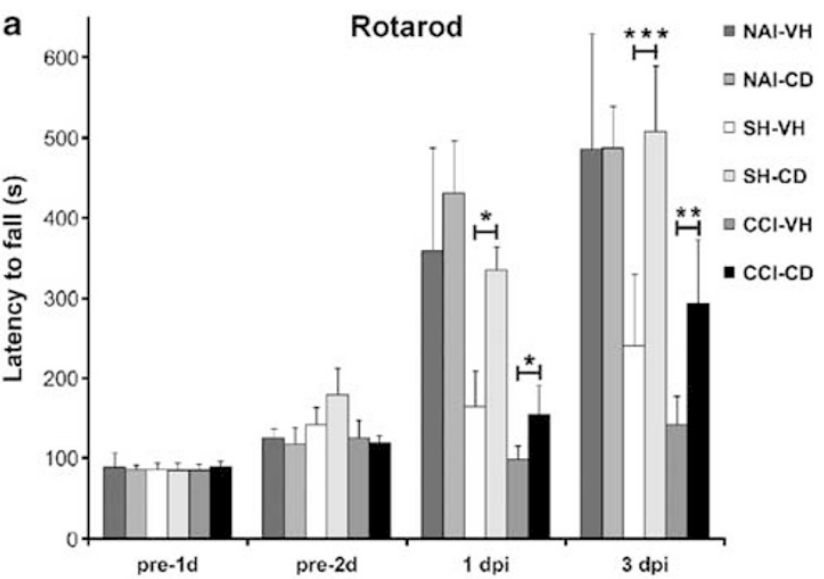

b

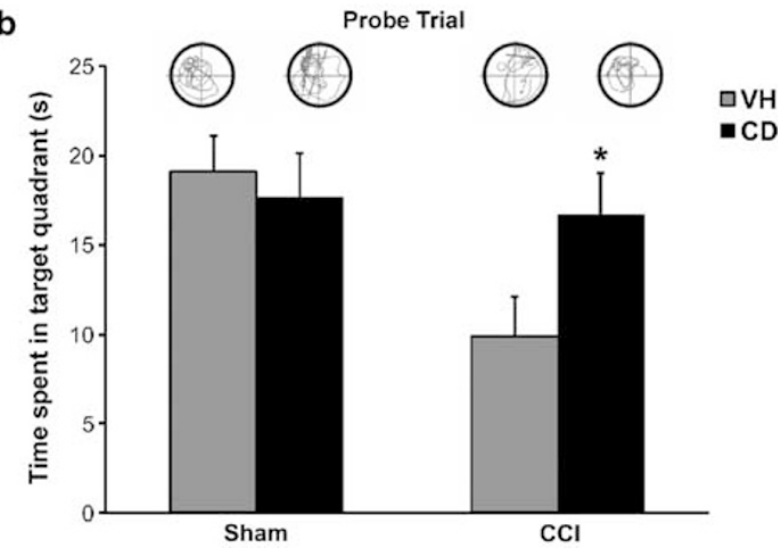

Figure 5 Candesartan treatment improves motor and cognitive function in mice after $\mathrm{CCl}$. (a) Time (seconds) that mice were able to remain on the rotarod in pre-training and at I and 3 days post-injury (dpi). Candesartan treatment (CD) enhanced the ability of mice to stay on the rotarod after either sham $(\mathrm{SH})$ surgery or $\mathrm{CCl}$ mice compared with vehicle $(\mathrm{VH})$-treated mice but did not alter the ability of naive (NAl) mice to perform this test (mean \pm SEM, $n=8-12$, ***** $p<0.008$, ${ }^{*} * p<0.005$, * $p<0.05$ ) at I and 3 dpi. (b) MWM testing showed that after $C C l$ injury mice treated with $C D$ spent more time in the northwest (NW) quadrant from where the platform was removed in the probe trial, compared with mice receiving $\mathrm{VH}$ at $28 \mathrm{dpi}$. Thus, CD treatment led to a greater ability to learn and remember the location of a hidden platform (mean $\pm \mathrm{SEM}, n=5 \mathrm{SH}-\mathrm{VH}$, $n=3 \mathrm{SH}-\mathrm{CD}, n=7 \mathrm{CCl}-\mathrm{VH}, n=8 \mathrm{CCl}-\mathrm{CD}, * 0<0.05)$.

2002; Nishimura et al, 2000; Zhou et al, 2006). When measured $18 \mathrm{~h}$ after CCI, we found that in mice treated with candesartan the reduction in $\mathrm{CBF}$ returned to pre-injury levels, in comparison with the still depressed $\mathrm{CBF}$ in vehicle-treated mice after CCI (Figure 3). Our results concur with other reports showing that candesartan partially restored diminished CBF following fluid percussion brain injury in a neonatal pig model (Baranov and Armstead, 2003). Demonstrated effects of $\operatorname{PPAR} \gamma$ on the vasculature seem restricted to a long-term protective effect that may even be mediated via inhibition of the renin - angiotensin system, mediated by $\mathrm{AT}_{1} \mathrm{R}$ (Sugawara et al, 2011). Thus, the ability of candesartan to protect CBF after TBI demonstrates the important role of cerebrovascular $\mathrm{AT}_{1} \mathrm{R}$ blockade (Zhou et al, 2006).

$\operatorname{TGF} \beta 1$ is an important cytokine that is rapidly induced following TBI (Wang et al, 2007). It has many functions in the nervous system, which are both beneficial and detrimental to the recovery from TBI including promoting glial scar formation (Chodobski et al, 2003; Vivien and Ali, 2006; Wang et al, 2007). Ang II can induce the expression or activation of TGF $\beta 1$ in many different tissues (Harasawa et al, 2010; Jiao et al, 2011; Sun et al, 1998; Yu et al, 2001). Indeed, TGF $\beta 1$ mediates Ang II dependent functions in the heart (Rosenkranz, 2004). In the spinal cord, Lanz et al. (2010) show that Ang II-dependent neuroinflammation in an experimental autoimmune encephalomyelitis model is mediated through upregulation of TGF $\beta$, and that candesartan ameliorated this neuroinflammation acting through $\mathrm{AT}_{1} \mathrm{Rs}$ in astrocytes and microglia. We found that candesartan potently reduces TGF $\beta 1$ expression in cortical and hippocampal astrocytes following CCI injury. Therefore, our results support the concept that TGF $\beta 1$ acts as a downstream mediator of Ang II in the nervous system. Conversely and somewhat surprisingly, we found that candesartan treatment led to an upregulation of $\operatorname{TGF} \beta 3$ expression in cortical and hippocampal astrocytes. TGF $\beta 3$, despite its similarity to TGF $\beta 1$, favors repair processes, and has been used in clinical trials for scar reduction in the skin (Occleston et al, 2008). Thus, candesartan differentially regulates two different TGF $\beta$ family members through unknown mechanisms. The significance of the candesartanmediated induction of TGF $\beta 3$ levels is not known.

Increased neuronal cell death after TBI has many potential mechanisms including reduced blood flow, cerebral vasoconstriction, blood - brain barrier breakdown, excitotoxicity, oxidative stress, and pro-inflammatory processes (Barkhoudarian et al, 2011). Previous studies have demonstrated that candesartan reduces superoxide production and preserves antioxidant capacity after global cerebral ischemia (Sugawara et al, 2005) and after intracerebral hemorrhage (Jung et al, 2007). As $\mathrm{AT}_{1} \mathrm{R}$ expression in the cortex is low, it is probable that the reduction in lesion volume and neuroprotection mediated by candesartan is a result of a more global reduction in inflammation and oxidative stress, mediated by the actions of candesartan on other cell types, including the cerebral vasculature (Zhou et al, 2006). Following peripheral administration of bacterial endotoxin, candesartan decreases inflammation throughout the brain preventing microglia activation (Benicky et al, 2011). Candesartan also directly reduces markers of inflammation in neuronal, microglial, and cerebrovascular endothelial cell cultures (Benicky et al, 2011) and in human circulating monocytes (Larrayoz et al, 2009). Indeed, we found that candesartan treatment reduces the activation of microglial cells in the injured cortex after TBI (Figure 2). As microglial expression of $\mathrm{AT}_{1} \mathrm{R}$ is very low (data not shown), we postulate that effects beyond $\mathrm{AT}_{1} \mathrm{R}$ blockade may be at least partially responsible for the therapeutic effects of candesartan.

One major additional effect of candesartan is $\operatorname{PPAR} \gamma$ activation. The nuclear receptor $\mathrm{PPAR} \gamma$ is expressed in most if not all cells in the CNS, including astrocytes, oligodendrocytes, microglia, and neurons (Bernardo and Minghetti, 2006). PPAR $\gamma$ activation curtails inflammation through decreasing the expression and release of pro-inflammatory cytokines, and reducing the activation of microglial activation (Gillespie et al, 2011). PPAR $\gamma$ agonists have beneficial effects in a variety of animal models including spinal cord 

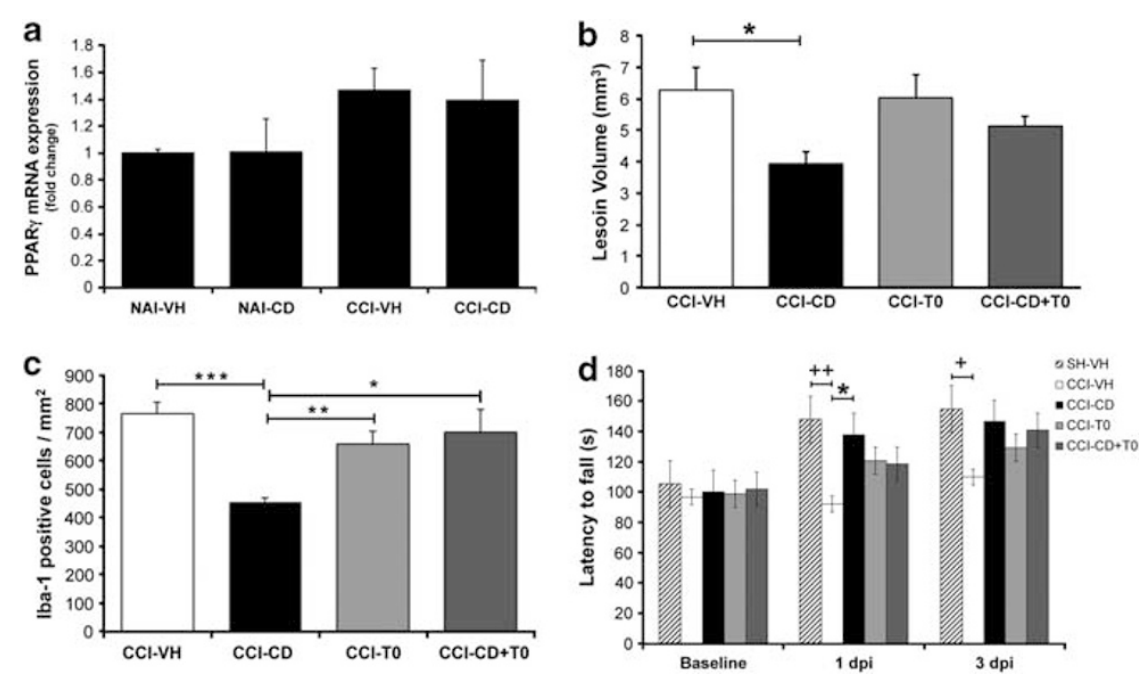

Figure 6 The influence of PPAR $\gamma$ antagonist on the neuroprotective effects of candesartan following brain injury. Mice were administered vehicle, candesartan (CD) and/or the PPAR $\gamma$ antagonist, T0070907 by daily injection for 3 days, starting $5 \mathrm{~h}$ before injury. (a) Effects on PPAR $\gamma$ mRNA expression. PPAR $\gamma$ mRNA expression was not significantly altered after injury $(\mathrm{CCl})$ and/or after $\mathrm{CD}$ treatment in the perilesional cortex as compared with vehicletreated naive (NAl) mice at $3 \mathrm{dpi}$ (mean $\pm \mathrm{SEM}, n=4)$. (b) Effects on lesion volume. At $3 \mathrm{dpi}, \mathrm{CD}$ significantly reduced the lesion volume $(* p<0.05, \mathrm{CCl}-\mathrm{VH}$ vs CCl-CD). T0070907 administration alone (CCl-T0) or together with $\mathrm{CD}(\mathrm{CCl}-\mathrm{CD}+\mathrm{T0})$ did not alter the lesion volume compared with the vehicle group (NS, $p>0.05$ ), nor was it significantly different than in mice treated with CD alone (NS, $p>0.05, \mathrm{CCl}-\mathrm{VH}$ vs CCI-CD + T0) (mean \pm SEM, $n=7-8)$. (c) Effects on Iba-I-positive microglial cells. CD significantly reduced the number of Iba-I-positive cells in the injured cortex $(* * * p<0.00 \mathrm{I}$, ** $p<0.005, \mathrm{CCl}$ $\mathrm{VH}$ vs CCl-CD). This effect was abolished by co-treatment with T0070907 (* $p<0.05, \mathrm{CCl}-\mathrm{CD}$ vs CCl-CD + T0). Treatment with T0070907 alone (CClT0) did not change the number of Iba- I-positive cells (NS, p >0.05, CCIVH vs CCl-TO) (mean \pm SEM, $n=4-7$ ). (d) Effects on the ability of mice to remain on the rotarod. $\mathrm{CCl}$ significantly reduced the ability of mice to remain on the rotarod $\left({ }^{+}+p<0.0 \mathrm{l}, \mathrm{SHVH}\right.$ vs $\left.\mathrm{CCl}-\mathrm{VH}\right)$. CD treatment alone significantly enhanced the ability of $\mathrm{CCl}$ injured mice to remain on the rotarod at I dpi ( ${ }^{*} p<0.05, \mathrm{CCl}-\mathrm{VH}$ vs $\left.\mathrm{CCl}-\mathrm{CD}\right)$. The protective effect of $\mathrm{CD}$ at I dpi was no longer significant after co-administration of T0070907 (NS, p > 0.05, CCI-VH vs CCI-CD-T0) (mean \pm SEM, $n=7$; data were analyzed by two-way ANOVA with Bonferroni post-tests). VH, vehicle; CD, candesartan; TO, T0070907; NS, not significant.

injury, stroke and TBI (Gillespie et al, 2011; McTigue et al, 2007; Zuhayra et al, 2011). The anti-inflammatory properties of PPAR $\gamma$ suggest that PPAR $\gamma$ activation may contribute to the anti-inflammatory effects of ARBs (Malchiodi-Albedi et al, 2008). Telmisartan is the ARB with the greatest PPAR $\gamma$ agonist activity (Benson et al, 2004). However, candesartan can also activate PPAR $\gamma$-mediated gene expression (Erbe et al, 2006; Zorad et al, 2006). Indeed, the significant reduction in the protective effects of candesartan by coadministration of a PPAR $\gamma$ antagonist (Figure 6) suggests that $\operatorname{PPAR} \gamma$ agonist activity forms a significant if not the major component of the beneficial, anti-inflammatory actions of candesartan. Candesartan did not appear to induce expression of PPAR $\gamma$ mRNA at 3 dpi (Figure 6). Instead, candesartan may bind directly to PPAR $\gamma$ as part of the heterodimer with retinoid $\mathrm{X}$ receptor causing dissociation of co-repressor molecules and recruitment of transcriptional coactivators to induce transcription (Erbe et al, 2006).

The relative role of $\mathrm{AT}_{1} \mathrm{R}$ blockade and PPAR $\gamma$ activation in the therapeutic effects of ARBs is still under investigation. The protection of $\mathrm{CBF}$, decreased vasoconstriction, regulation of TGF $\beta$ expression, and direct neuroprotective effects, are probably attributable to blockade of the $A_{1} R$. However, it appears that the contribution of $\mathrm{AT}_{1} \mathrm{R}$ blockade and PPAR $\gamma$ activation is dependent on cell type. For example, candesartan protects human circulating monocytes expressing very few $\mathrm{AT}_{1} \mathrm{Rs}$ by activating $\mathrm{PPAR} \gamma$ (Larrayoz et al, 2009). Conversely, the neuroprotective effect of another ARB, telmisartan in neuronal cultures expressing $\mathrm{AT}_{1} \mathrm{Rs}$, is independent of $\operatorname{PPAR} \gamma$ activation (Pang et al, 2012).

In our study, PPAR $\gamma$ inhibition abolished the significant protective effects of candesartan on microglial activation (Figure 6c). However, PPAR $\gamma$ inhibition reduced, but did not eliminate the beneficial effect of candesartan on lesion volume or motor function, as treatment with T0070907 together with candesartan was not significantly different from treatment with either vehicle or candesartan alone (Figures $6 \mathrm{~b}$ and $\mathrm{d}$ ). The PPAR $\gamma$ agonist activity of some ARBs, including candesartan, may not be independent of their $\mathrm{AT}_{1} \mathrm{R}$-blocking properties. There is cross-talk between $\mathrm{AT}_{1} \mathrm{R}$ and PPAR $\gamma$ activation (Xiao et al, 2009); PPAR $\gamma$ agonists reduce $\mathrm{AT}_{1} \mathrm{R}$-mediated inflammation and hypertension in vivo (Ji et al, 2009), and downregulates $\mathrm{AT}_{1} \mathrm{R}$ expression (Zhao et al, 2008), whereas Ang II, by stimulating the $\mathrm{AT}_{1} \mathrm{R}$, downregulates PPAR $\gamma$ activity (Tham et al, 2002). Further studies are necessary to elucidate the relative role of $\mathrm{AT}_{1} \mathrm{R}$ inhibition and PPAR $\gamma$ activation in neuroprotection after TBI. Nevertheless, use of the ARBs as treatment for TBI may have more efficacy because of the dual antiinflammatory action of inhibition of $\mathrm{AT}_{1} \mathrm{R}$ and activation of PPAR $\gamma$ (Yi et al, 2008).

While we were completing the studies presented here, Timaru-Kast et al (2012) published their study showing that a $0.1 \mathrm{mg} / \mathrm{kg}$ dose of candesartan, but not a $1 \mathrm{mg} / \mathrm{kg}$ dose, administered by subcutaneous injection up to $4 \mathrm{~h}$ after injury, reduced the lesion size after CCI injury in mice and improved the neurologic severity score. We found efficacy of candesartan at $1 \mathrm{mg} / \mathrm{kg} /$ day, administered by osmotic 
minipump, starting $5 \mathrm{~h}$ before injury. The difference in the efficacy of $1 \mathrm{mg} / \mathrm{kg} /$ day between our data and that of Timaru-Kast et al (2012) may be explained by different mechanisms of administration. There is a significant drop in blood pressure following TBI that could be detrimental (Guan et al, 2011; Sookplung et al, 2011). Thus, medication that lowers blood pressure further may be problematic in treating TBI. Candesartan can lower blood pressure at high doses (Omura-Matsuoka et al, 2009). Injection of $1 \mathrm{mg} / \mathrm{kg}$ candesartan immediately following injury may be more detrimental than injecting it $5 \mathrm{~h}$ before injury. Indeed, Timaru-Kast et al, (2012) found that $1 \mathrm{mg} / \mathrm{kg}$ significantly lowered blood pressure. With the use of indirect tail cuff measurements, we found only a slight nonsignificant drop in blood pressure (Figure 3). It is probable that the neuroprotective effects of candesartan are not dependent on its hypotensive action, and thus the dose dependence of neuroprotection and blood pressure reduction can be separated. Indeed, beneficial effects of candesartan after stroke have been shown for doses that are not hypotensive (Omura-Matsuoka et al, 2009). The results of Timaru-Kast et al (2012), show that post-injury administration of candesartan up to $4 \mathrm{~h}$ after injury are beneficial to recovery when assessed at $24 \mathrm{~h}$ after injury. We have shown that the beneficial cognitive effects of candesartan can be detected up to 28 days after injury. Ultimately, for ARBs to be pursued as therapeutics, we need to determine the maximum time window after injury for candesartan administration to retain its efficacy in improving functional recovery 1 or 2 months after injury.

Together our data show that treatment with ARBs in mice attenuated the TBI-induced neuronal death, in part through reducing the amount of inflammatory response. This improvement in pathology bestowed improved cognitive and motor functional outcomes after injury. The reduced lesion size, and enhanced cell survival translated into longer-term improvement in cognitive memory, as shown by the improved function in the MWM. To our knowledge, this is the first study that shows that candesartan can enhance recognition and spatial memory 4 weeks after TBI. Thus, candesartan, and therefore potentially other ARBs that cross the blood - brain barrier, could be promising therapeutics for TBI. The ability of these drugs to address several different mechanisms simultaneously makes them particularly attractive treatments for TBI.

\section{ACKNOWLEDGEMENTS}

This study was supported by a pilot award from the Center for Neuroscience and Regenerative Medicine (CNRM) grant (AJS). SV is supported by a CNRM postdoctoral fellowship. JMS and ESL are supported by the Division of Intramural Research Programs, National Institute of Mental Health, National Institutes of Health. We thank Laura Tucker, Oz Malkesman, and Amanda Fu from the CNRM pre-clinical core facility for expert advice, Dr Tim ÓNeil for his assistance with blood pressure measurements. We are grateful to members of the Symes and Saavedra laboratories for their helpful comments and suggestions. The opinions and assertions contained herein are the private opinions of the authors and are not to be construed as reflecting the views of the Uniformed Services University of the Health Sciences or the US Department of Defense.

\section{DISCLOSURE}

The authors declare no conflict of interest.

\section{REFERENCES}

An J, Nakajima T, Kuba K, Kimura A (2010). Losartan inhibits LPS-induced inflammatory signaling through a PPARgammadependent mechanism in human THP-1 macrophages. Hypertens Res Off J Jap Soc Hypertens 33: 831-835.

Ando H, Jezova M, Zhou J, Saavedra JM (2004a). Angiotensin II AT1 receptor blockade decreases brain artery inflammation in a stress-prone rat strain. Ann N Y Acad Sci 1018: 345-350.

Ando H, Zhou J, Macova M, Imboden H, Saavedra JM (2004b). Angiotensin II AT1 receptor blockade reverses pathological hypertrophy and inflammation in brain microvessels of spontaneously hypertensive rats. Stroke 35: 1726-1731.

Ariza M, Matarin MD, Junque C, Mataro M, Clemente I, Moral P et al (2006). Influence of Angiotensin-converting enzyme polymorphism on neuropsychological subacute performance in moderate and severe traumatic brain injury. J Neuropsychiatry Clin Neurosci 18: 39-44.

Awad AS (2011). Effect of combined treatment with curcumin and candesartan on ischemic brain damage in mice. J Stroke Cerebrovasc Dis 20: 541-548.

Baranov D, Armstead WM (2003). Selective blockade of AT1 receptor attenuates impairment of hypotensive autoregulation and improves cerebral blood flow after brain injury in the newborn pig. Anesthesiology 99: 1118-1124.

Barkhoudarian G, Hovda DA, Giza CC (2011). The molecular pathophysiology of concussive brain injury. Clin Sports Med 30: 33-48 vii-iii.

Benicky J, Sanchez-Lemus E, Honda M, Pang T, Orecna M, Wang J et al (2011). Angiotensin II AT(1) receptor blockade ameliorates brain inflammation. Neuropsychopharmacology 36: 857-870.

Benigni A, Cassis P, Remuzzi G (2010). Angiotensin II revisited: new roles in inflammation, immunology and aging. EMBO Mol Med 2: 247-257.

Benson SC, Pershadsingh HA, Ho CI, Chittiboyina A, Desai P, Pravenec $\mathrm{M}$ et al (2004). Identification of telmisartan as a unique angiotensin II receptor antagonist with selective PPARgammamodulating activity. Hypertension 43: 993-1002.

Bernardo A, Minghetti L (2006). PPAR-gamma agonists as regulators of microglial activation and brain inflammation. Curr Pharm Des 12: 93-109.

Burson JM, Aguilera G, Gross KW, Sigmund CD (1994). Differential expression of angiotensin receptor $1 \mathrm{~A}$ and $1 \mathrm{~B}$ in mouse. $\mathrm{Am} \mathrm{J}$ Physiol 267: E260-267.

Chodobski A, Chung I, Kozniewska E, Ivanenko T, Chang W, Harrington JF et al (2003). Early neutrophilic expression of vascular endothelial growth factor after traumatic brain injury. Neuroscience 122: 853-867.

Davies NM, Kehoe PG, Ben-Shlomo Y, Martin RM (2011). Associations of anti-hypertensive treatments with Alzheimer's disease, vascular dementia, and other dementias. J Alzheimers Dis 26: 699-708.

Davisson RL, Oliverio MI, Coffman TM, Sigmund CD (2000). Divergent functions of angiotensin II receptor isoforms in the brain. J Clin Invest 106: 103-106.

Engelhorn T, Goerike S, Doerfler A, Okorn C, Forsting M, Heusch G et al (2004). The angiotensin II type 1-receptor blocker candesartan increases cerebral blood flow, reduces 
infarct size, and improves neurologic outcome after transient cerebral ischemia in rats. J Cereb Blood Flow Metab 24: 467-474.

Erbe DV, Gartrell K, Zhang YL, Suri V, Kirincich SJ, Will S et al (2006). Molecular activation of PPARgamma by angiotensin II type 1-receptor antagonists. Vascul Pharmacol 45: 154-162.

Fogari R, Zoppi A (2004). Effect of antihypertensive agents on quality of life in the elderly. Drugs Aging 21: 377-393.

Gillespie W, Tyagi N, Tyagi SC (2011). Role of PPARgamma, a nuclear hormone receptor in neuroprotection. Indian J Biochem Biophys 48: 73-81.

Guan W, Kozak A, El-Remessy AB, Johnson MH, Pillai BA, Fagan SC (2011). Acute Treatment with Candesartan Reduces Early Injury After Permanent Middle Cerebral Artery Occlusion. Transl Stroke Res 2: 179-185.

Hamm RJ (2001). Neurobehavioral assessment of outcome following traumatic brain injury in rats: an evaluation of selected measures. J Neurotrauma 18: 1207-1216.

Hansson L, Lithell H, Skoog I, Baro F, Banki CM, Breteler M et al (1999). Study on COgnition and Prognosis in the Elderly (SCOPE). Blood Press 8: 177-183.

Harasawa S, Otsuka Y, Okubo K, Koike M, Fujita H, Kushiro T et al (2010). Amlodipine suppressed cardiac gene expression of brain natriuretic peptide, transforming growth factor-beta and fibronectin mediated by aldosterone in male strokeprone spontaneously hypertensive rats. J Pharm Pharmacol 62: $1740-1745$

Igase M, Kohara K, Miki T (2012). The Association between Hypertension and Dementia in the Elderly. Int J Hypertens 2012: 320648.

Ito T, Nishimura Y, Saavedra J (2001). Pre-treatment with candesartan protects from cerebral ischaemia. J Renin Angiotensin Aldosterone Syst 2: 174-179.

Ito T, Yamakawa $\mathrm{H}$, Bregonzio C, Terron JA, Falcon-Neri A, Saavedra JM (2002). Protection against ischemia and improvement of cerebral blood flow in genetically hypertensive rats by chronic pretreatment with an angiotensin II AT1 antagonist. Stroke 33: 2297-2303.

Ji Y, Liu J, Wang Z, Liu N, Gou W (2009). PPARgamma agonist, rosiglitazone, regulates angiotensin II-induced vascular inflammation through the TLR4-dependent signaling pathway. Lab Invest J Tech Methods Pathol 89: 887-902.

Jiao B, Wang YS, Cheng YN, Gao JJ, Zhang QZ (2011). Valsartan attenuated oxidative stress, decreased MCP-1 and TGF-betal expression in glomerular mesangial and epithelial cells induced by high-glucose levels. Biosci Trends 5: 173-181.

Johren O, Saavedra JM (1996). Expression of AT1A and AT1B angiotensin II receptor messenger RNA in forebrain of 2-wk-old rats. Am J Physiol 271: E104-112.

Jung KH, Chu K, Lee ST, Kim SJ, Song EC, Kim EH et al (2007). Blockade of AT1 receptor reduces apoptosis, inflammation, and oxidative stress in normotensive rats with intracerebral hemorrhage. J Pharmacol Exp Ther 322: 1051-1058.

Kasahara Y, Taguchi A, Uno H, Nakano A, Nakagomi T, Hirose H et al (2010). Telmisartan suppresses cerebral injury in a murine model of transient focal ischemia. Brain Res 1340: 70-80.

Lanz TV, Ding Z, Ho PP, Lou J, Agrawal AN, Srinagesh H et al (2010). Angiotensin II sustains brain inflammation in mice via TGF- $\beta$. J Clin Invest 120: 2782-2794.

Larrayoz IM, Pang T, Benicky J, Pavel J, Sanchez-Lemus E, Saavedra JM (2009). Candesartan reduces the innate immune response to lipopolysaccharide in human monocytes. J Hypertens 27: 2365-2376.

Li JM, Mogi M, Iwanami J, Min LJ, Tsukuda K, Sakata A et al (2008). Temporary pretreatment with the angiotensin II type 1 receptor blocker, valsartan, prevents ischemic brain damage through an increase in capillary density. Stroke 39: 2029-2036.

Liu H, Kitazato KT, Uno M, Yagi K, Kanematsu Y, Tamura T et al (2008). Protective mechanisms of the angiotensin II type 1 receptor blocker candesartan against cerebral ischemia: in-vivo and in-vitro studies. J Hypertens 26: 1435-1445.

Loane DJ, Faden AI (2010). Neuroprotection for traumatic brain injury: translational challenges and emerging therapeutic strategies. Trends Pharmacol Sci 31: 596-604.

Maeda A, Okazaki $T$, Inoue $M$, Kitazono $T$, Yamasaki $M$, Lemonnier FA et al (2009). Immunosuppressive effect of angiotensin receptor blocker on stimulation of mice CTLs by angiotensin II. Int Immunopharmacol 9: 1183-1188.

Malchiodi-Albedi F, Matteucci A, Bernardo A, Minghetti L (2008). PPAR-gamma, microglial cells, and ocular inflammation: new venues for potential therapeutic approaches. PPAR Res 2008: 295784.

Marklund N, Hillered L (2011). Animal modelling of traumatic brain injury in preclinical drug development: where do we go from here? Br J Pharmacol 164: 1207-1229.

McTigue DM, Tripathi R, Wei P, Lash AT (2007). The PPAR gamma agonist pioglitazone improves anatomical and locomotor recovery after rodent spinal cord injury. Experimental neurology 205: 396-406.

Meredith PA, Murray LS, McMurray JJ (2004). A putative placebo comparison of the SCOPE and LIFE trials. J Renin Angiotensin Aldosterone Syst 5: 59-63.

Nishimura Y, Ito T, Hoe K, Saavedra JM (2000). Chronic peripheral administration of the angiotensin II AT(1) receptor antagonist candesartan blocks brain AT(1) receptors. Brain Res 871: 29-38.

O'Connor WT, Smyth A, Gilchrist MD (2011). Animal models of traumatic brain injury: a critical evaluation. Pharmacol Ther 130: 106-113.

Occleston NL, Laverty HG, O'Kane S, Ferguson MW (2008). Prevention and reduction of scarring in the skin by transforming growth factor beta 3 (TGFbeta3): from laboratory discovery to clinical pharmaceutical. J Biomater Sci Polym Ed 19: 1047-1063.

Omura-Matsuoka E, Yagita Y, Sasaki T, Terasaki Y, Oyama N, Sugiyama Y et al (2009). Postischemic administration of angiotensin II type 1 receptor blocker reduces cerebral infarction size in hypertensive rats. Hypertens Res 32: 548-553.

Ozacmak VH, Sayan H, Cetin A, Akyildiz-Igdem A (2007). AT1 receptor blocker candesartan-induced attenuation of brain injury of rats subjected to chronic cerebral hypoperfusion. Neurochem Res 32: 1314-1321.

Pang T, Benicky J, Wang J, Orecna M, Sanchez-Lemus E, Saavedra JM (2012). Telmisartan ameliorates lipopolysaccharide-induced innate immune response through peroxisome proliferatoractivated receptor-gamma activation in human monocytes. J Hypertens 30: 87-96.

Paul M, Poyan Mehr A, Kreutz R (2006). Physiology of local reninangiotensin systems. Physiol Rev 86: 747-803.

Poon IO (2008). Effects of antihypertensive drug treatment on the risk of dementia and cognitive impairment. Pharmacotherapy 28: 366-375.

Ricote M, Li AC, Willson TM, Kelly CJ, Glass CK (1998). The peroxisome proliferator-activated receptor-gamma is a negative regulator of macrophage activation. Nature 391: 79-82.

Robbins ME, Zhao W, Garcia-Espinosa MA, Diz DI (2010). Reninangiotensin system blockers and modulation of radiationinduced brain injury. Curr Drug Targets 11: 1413-1422.

Rodriguez-Pallares J, Rey P, Parga JA, Munoz A, Guerra MJ, Labandeira-Garcia JL (2008). Brain angiotensin enhances dopaminergic cell death via microglial activation and NADPHderived ROS. Neurobiol Dis 31: 58-73.

Rosenkranz S (2004). TGF-beta1 and angiotensin networking in cardiac remodeling. Cardiovasc Res 63: 423-432.

Rotman N, Wahli W (2010). PPAR modulation of kinase-linked receptor signaling in physiology and disease. Physiology (Bethesda) 25: 176-185.

Saavedra JM (1992). Brain and pituitary angiotensin. Endocr Rev 13: $329-380$. 
Saavedra JM, Sanchez-Lemus E, Benicky J (2011). Blockade of brain angiotensin II AT1 receptors ameliorates stress, anxiety, brain inflammation and ischemia: therapeutic implications. Psychoneuroendocrinology 36: 1-18.

Santos CC, Zhang H, Liu M, Slutsky AS (2005). Bench-to-bedside review: biotrauma and modulation of the innate immune response. Crit Care 9: 280-286.

Savoia C, Schiffrin EL (2007). Vascular inflammation in hypertension and diabetes: molecular mechanisms and therapeutic interventions. Clin Sci (Lond) 112: 375-384.

Sookplung P, Siriussawakul A, Malakouti A, Sharma D, Wang J, Souter MJ et al (2011). Vasopressor use and effect on blood pressure after severe adult traumatic brain injury. Neurocrit Care 15: 46-54.

Stenman E, Edvinsson L (2004). Cerebral ischemia enhances vascular angiotensin AT1 receptor-mediated contraction in rats. Stroke 35: 970-974.

Sugawara A, Uruno A, Matsuda K, Funato T, Saito-Hakoda A, Kudo $\mathrm{M}$ et al (2011). Effects of PPARgamma agonists against vascular and renal dysfunction. Curr Mol Pharmacol.

Sugawara T, Kinouchi H, Oda M, Shoji H, Omae T, Mizoi K (2005). Candesartan reduces superoxide production after global cerebral ischemia. Neuroreport 16: 325-328.

Sun Y, Zhang JQ, Zhang J, Ramires FJ (1998). Angiotensin II, transforming growth factor-betal and repair in the infarcted heart. J Mol Cell Cardiol 30: 1559-1569.

Susarla BT, Laing ED, Yu P, Katagiri Y, Geller HM, Symes AJ (2011). Smad proteins differentially regulate transforming growth factor- $\beta$ mediated induction of chondrotin sulfate proteoglycans. J Neurochem 119: 868-878.

Tham DM, Martin-McNulty B, Wang YX, Wilson DW, Vergona R, Sullivan ME et al (2002). Angiotensin II is associated with activation of NF-kappaB-mediated genes and downregulation of PPARs. Physiol Genomics 11: 21-30.

Thone-Reineke C, Steckelings UM, Unger T (2006). Angiotensin receptor blockers and cerebral protection in stroke. J Hypertens Suppl 24: S115-121.

Timaru-Kast R, Wyschkon S, Luh C, Schaible EV, Lehmann F, Merk P et al (2012). Delayed inhibition of angiotensin II receptor type 1 reduces secondary brain damage and improves functional recovery after experimental brain trauma*. Crit Care Med 40: 935-944.

Tsutsumi K, Saavedra JM (1991). Characterization and development of angiotensin II receptor subtypes (AT1 and AT2) in rat brain. Am J Physiol 261: R209-216.

Van Mieghem W, Billiouw JM, Brohet C, Dupont AG, Gazagnes MD, Heller F et al (2010). Are ACE-inhibitors or ARB's still needed for cardiovascular prevention in high risk patients? Insights from profess and transcend. Acta Clin Belg 65: 107-114.

Villapol S, Fau S, Renolleau S, Biran V, Charriaut-Marlangue C, Baud O (2011). Melatonin promotes myelination by decreasing white matter inflammation after neonatal stroke. Pediatr Res 69: 51-55.

Vivien D, Ali C (2006). Transforming growth factor-beta signalling in brain disorders. Cytokine Growth Factor Rev 17: 121-128.

Wang Y, Moges H, Bharucha Y, Symes A (2007). Smad3 null mice display more rapid wound closure and reduced scar formation after a stab wound to the cerebral cortex. Exp Neurol 203: $168-184$.

Xiao J, Leung JC, Chan LY, Tang SC, Lai KN (2009). Crosstalk between peroxisome proliferator-activated receptor-gamma and angiotensin II in renal tubular epithelial cells in IgA nephropathy. Clin Immunol 132: 266-276.

Yamakawa H, Jezova M, Ando H, Saavedra JM (2003). Normalization of endothelial and inducible nitric oxide synthase expression in brain microvessels of spontaneously hypertensive rats by angiotensin II AT1 receptor inhibition. J Cereb Blood Flow Metab 23: 371-380.

Yi JH, Park SW, Brooks N, Lang BT, Vemuganti R (2008). PPARgamma agonist rosiglitazone is neuroprotective after traumatic brain injury via anti-inflammatory and anti-oxidative mechanisms. Brain Res 1244: 164-172.

Yu CM, Tipoe GL, Wing-Hon Lai K, Lau CP (2001). Effects of combination of angiotensin-converting enzyme inhibitor and angiotensin receptor antagonist on inflammatory cellular infiltration and myocardial interstitial fibrosis after acute myocardial infarction. J Am Coll Cardiol 38: 1207-1215.

Zanchetti A, Elmfeldt D (2006). Findings and implications of the Study on COgnition and Prognosis in the Elderly (SCOPE) - a review. Blood Press 15: 71-79.

Zhao SM, Shen LH, Li HW, Wang L, Chen H, Wang YL et al (2008). Down-regulation of the expression of angiotensin II type 1 receptor in neonatal rat cardiac fibroblast by activation of PPARgamma signal pathway. Chin J Physiol 51: 357-362.

Zhou J, Ando H, Macova M, Dou J, Saavedra JM (2005). Angiotensin II AT1 receptor blockade abolishes brain microvascular inflammation and heat shock protein responses in hypertensive rats. J Cereb Blood Flow Metab 25: 878-886.

Zhou J, Pavel J, Macova M, Yu ZX, Imboden H, Ge L et al (2006). AT1 receptor blockade regulates the local angiotensin II system in cerebral microvessels from spontaneously hypertensive rats. Stroke 37: 1271-1276.

Zorad S, Dou JT, Benicky J, Hutanu D, Tybitanclova K, Zhou J et al (2006). Long-term angiotensin II AT1 receptor inhibition produces adipose tissue hypotrophy accompanied by increased expression of adiponectin and PPARgamma. Eur J Pharmacol 552: 112-122.

Zuhayra M, Zhao Y, von Forstner C, Henze E, Gohlke P, Culman J et al (2011). Activation of cerebral peroxisome proliferatoractivated receptors gamma (PPARgamma) reduces neuronal damage in the substantia nigra after transient focal cerebral ischaemia in the rat. Neuropathol Appl Neurobiol 37: 738-752.

Supplementary Information accompanies the paper on the Neuropsychopharmacology website (http://www.nature.com/npp) 